\title{
Plant species, temperature, and bedrock affect net methane flux out of grassland and forest soils
}

\author{
Nadine Praeg • Andreas O. Wagner • Paul Illmer
}

Received: 16 March 2016 / Accepted: 13 July 2016/Published online: 30 July 2016

(C) The Author(s) 2016. This article is published with open access at Springerlink.com

\begin{abstract}
Aims The objectives of this study were to investigate the influence of plants on net methane flux from forest and grassland soils depending on bedrock, temperature, and plant species, and to determine the abundance of methanogenic and methanotrophic microorganisms.

Methods Lab-scale gas measurements with forest and grassland soils and different site-specific plants were performed. Next-generation sequencing was conducted to characterize the archaeal community structure and the abundance of methanotrophic bacteria was determined via quantitative PCR.

Results Forest and grassland soils had a high potential to consume methane under ambient conditions. Irrespective of bedrock and plant species, a highly significant influence of temperature was established. The studied site-specific grassland plants Plantago lanceolata and $P$ oa pratensis significantly increased methane balance with varying extent depending on temperature. In contrast, the studied forest plants Picea abies and especially Larix decidua significantly boosted methane consumption. The flux measurements pointed to higher net methane consumption rates on limestone compared to
\end{abstract}

Responsible Editor: Per Ambus

Electronic supplementary material The online version of this article (doi:10.1007/s11104-016-2993-z) contains supplementary material, which is available to authorized users.

N. Praeg $(\square) \cdot$ A. O. Wagner $\cdot$ P. Illmer Institute of Microbiology, University of Innsbruck, Technikerstrasse 25d, A-6020 Innsbruck, Austria e-mail: Nadine.Praeg@uibk.ac.at siliceous bedrock. The proportion of Euryarchaeota including methanogens- increased in rhizosphere soil of grassland plants compared to bulk soil whereas methanotrophic abundances did not differ between bulk and rhizosphere soil.

Conclusions Results highlight that the methane fluxes in uplands soils are altered depending on plant species, temperature, and vegetation type and emphasize the need to better resolve the influence of plants on the methane cycle and the involved microorganisms.

Keywords Methanotrophs $\cdot$ Methanogens $\cdot$ Archaea . Greenhouse gas $\cdot$ Rhizosphere $\cdot$ Upland soil $\cdot$ Plants $\cdot \mathrm{CH}_{4}$

\section{Introduction}

Methane $\left(\mathrm{CH}_{4}\right)$ is an important greenhouse gas and its concentration in the atmosphere has increased from $0.7 \mathrm{ppm}$ in pre-industrial times to $1.8 \mathrm{ppm}$ at the moment (Dlugokencky et al. 1998; Kirschke et al. 2013). Despite this low concentration, its contribution to climate warming is approximately $20 \%$, as the absorption of infrared radiation is about 20 to 30 times stronger than of $\mathrm{CO}_{2}$ (Milich 1999; Ottow 2011; Stiehl-Braun et al. 2011). Most of the methane from natural sources originates from biological processes due to the activities of methanogenic Archaea. Methane is the end product of a sequence of processes that degrade organic carbon in an $\mathrm{O}_{2}$-limited environment (Megonigal et al. 2004). Methanogenic activities are restricted to low oxydoreduction potential $(\mathrm{Eh}<200 \mathrm{mV}$ ) and coupled to the 
occurrence of specific coenzymes (Ferry 2010). Therefore, methanogens are usually thought to be sensitive to $\mathrm{O}_{2}$, and to be only capable of growing and producing methane under strict anoxic conditions. However, recent studies revealed that various methanogens, especially Methanosarcina and Methanocella, can tolerate oxygen exposure but the underlying processes for this tolerance are still not well understood (Angel et al. 2011).

The only relevant biological methane sink is the oxidation of methane by methane oxidizing microorganisms. This process occurs in nearly all aerobic and to a lesser extent in anaerobic habitats (Knief et al. 2003). The biological oxidation of methane is mediated by methanotrophic Bacteria that use $\mathrm{CH}_{4}$ as their main source of carbon and energy (Knief 2015). Traditionally, methanotrophs have been divided into Type I and Type II, belonging to the Gammaproteobacteria and Alphaproteobacteria, respectively (Hanson and Hanson 1996; Knief 2015). The classification is based on $16 \mathrm{~S}$ rRNA phylogeny, carbon assimilation pathways, PLFA profiles, and the architecture of their intracellular membrane system (Hanson and Hanson 1996; Knief 2015). Despite the recent discovery of species that do not fit into this concept (Knief 2015), this traditional classification is still useful and applied (Urmann et al. 2009). The pmoA gene encoding for the $\alpha$-subunit of the particulate methane mono-oxygenase which is responsible for the initial conversion of $\mathrm{CH}_{4}$ to methanol is the most frequently used marker as it can be found in almost all aerobic methanotrophic Bacteria with exceptions among the Beijerinckiaceae (Knief 2015; Kolb et al. 2003). Methanotrophic Bacteria grow by coupling the oxidation of $\mathrm{CH}_{4}$ to the reduction of $\mathrm{O}_{2}$. They occur ubiquitous in soils and are responsible for the sink effect of upland soils. This is not only valid for atmospheric methane thus acting as a distinct sink for the already existing climate relevant $\mathrm{CH}_{4}$. More relevant, however, while diffusing through the soil, 60 to more than $90 \%$ of the methane produced by methanogens can be oxidized by methanotrophs, by which the latter prevent methane to be emitted to the atmosphere (Conrad 2009; Le Mer and Roger 2001).

Soils represent very heterogeneous and complex habitats offering a wide spectrum of micro-niches with variable properties. Among them, anoxic-niches allow the growth of methanogenic Archaea and the production of methane although oxygen and water content of upland soils seem to be inhibitory (Angel et al. 2012). Schaufler et al. (2010) reported strong spatial variations and 'hot spots' in emissions of greenhouse gases from soils, which are caused by the heterogeneous distribution of methanogens. However, several studies of upland soils report at least occasionally emissions of $\mathrm{CH}_{4}$ to the atmosphere which could often be traced back to changes in soil water content, ammonium concentration, and land use (Angel et al. 2012; Praeg et al. 2014; Prem et al. 2014; Schaufler et al. 2010; Wagner et al. 2012). Regarding land use, Ho et al. (2015) showed that agricultural soils that are generally regarded as weak methane sinks or even methane sources can be transiently converted into methane sinks by nutrient amendments in the form of residues. Nevertheless, given the right conditions (e.g., temperature and water content) upland soils can emit $\mathrm{CH}_{4}$ (Angel et al. 2012; Karbin et al. 2015) and they have been reported to quickly switch from net $\mathrm{CH}_{4}$ uptake to $\mathrm{CH}_{4}$ emission. Therefore, upland soils are -based on its enormous area- an important factor for the global methane cycle (Amaral et al. 1998; Le Mer and Roger 2001; Maurer et al. 2008; Nazaries et al. 2013; Wieczorek et al. 2011).

Very little attention has been paid on the investigation regarding the influence of plants on methane flux of upland soils. After the controversial discussion, induced by the proposed capability of plants to produce methane (Keppler et al. 2006), the importance of plants for the methane cycle was again restricted to their role as a transporter. Aerenchyma of wetland plants were considered to enable methane emissions into the atmosphere as this tissue acts as a chimney for methane produced in wetlands. Plant controls on methane fluxes are not limited to aerenchymatous transport only. Robroek et al. (2015) found that plant removal from study sites led to increased methane oxidation and decreased methane production potentials and showed that changed methane dynamics can be traced back to changes within the microbial communities including fungi. Very interesting results were also achieved in experiments investigating the impact of plants on C-cycling and methane emissions in soils (Ström et al. 2003) - showing that photosynthetic rates influenced the availability of acetate and thus in return the formation of $\mathrm{CH}_{4}$. However, these studies were performed with wetland soils and plants and focused on the impact of photosynthesis. Whilst knowledge on the drivers of methane cycling is growing for wetland ecosystems, we are still limited in our understanding for upland soils. We aim to bridge that knowledge gap by studying the effect of plants, temperature, and bedrock on methane cycles in upland soils. Specifically, we address the following hypotheses: 
1) $\mathrm{CH}_{4}$ flux in upland soils is influenced by temperature, bedrock, and plants. 2) Effects of plants on $\mathrm{CH}_{4}$ flux are species-dependent. 3) Plant-specific differences are also reflected within the community composition of Archaea and the abundance of methanotrophic Bacteria in the rhizosphere.

\section{Materials and methods}

Sites description and soil sampling

The present study used soils from two forest and two grassland sites located in the Inn Valley in Northern Tyrol. Soil sites were chosen to represent soils from limestone and siliceous bedrock. The forest site on limestone is located in Fritzens $\left(47^{\circ} 309^{\prime} \mathrm{N}, 1^{\circ} 603^{\prime} \mathrm{E}\right)$ and the one on siliceous bedrock in Flaurling Berg $\left(47^{\circ} 278^{\prime} \mathrm{N}\right.$, $\left.11^{\circ} 127^{\prime} \mathrm{E}\right)$. The grassland sites lie in Mieming $\left(47^{\circ} 315^{\prime} \mathrm{N}, 11^{\circ} 021^{\prime} \mathrm{E}\right)$ in case of limestone and on siliceous bedrock in Volderberg $\left(47^{\circ} 275^{\prime} \mathrm{N}, 11^{\circ} 549^{\prime} \mathrm{E}\right)$. According to the world reference base for soil resources (WRB) cambisol was the soil type on all sites. The sites cover an annual average temperature of $8.6^{\circ} \mathrm{C}$ and an annual precipitation range of $800-900 \mathrm{~mm}$. Forest sites are dominated by spruce whereas grassland sites represent meadows with typical meadow vegetation including Plantago lanceolata, Poa pratensis, Lolium perenne, Dactylus glomerata, Ranunculus bulbosa, Taraxacum officinale, Trifolium pratense and Trifolium repens. Soil sampling was carried out in August/September 2013. After removal of the plants, material of the soil's upper mineral horizon (at a depth of about 12-20 cm), just beneath the roots, was collected from at least ten locations that were subsequently merged into one soil sample. The soil was transported to the laboratory, immediately sieved to $<4 \mathrm{~mm}$ for the pot experiments and lab-scale gas measurements and $<2 \mathrm{~mm}$ for physical and chemical analysis and stored at $4{ }^{\circ} \mathrm{C}$.

Physical and chemical soil properties

Dry mass was determined by drying $10 \mathrm{~g}$ of the soil samples at $105{ }^{\circ} \mathrm{C}$ overnight. Soil $\mathrm{pH}$ was measured in a $\mathrm{CaCl}_{2}[0.01 \mathrm{M}]$ solution at a soil:solution ratio of $1: 2.5$ at room temperature. Soil organic matter was determined by the loss on ignition method at $430{ }^{\circ} \mathrm{C}$ (Schinner et al. 1996). The detection of plant-available ammonium was determined following an adapted dyeing based on
Berthelot (Kandeler and Gerber 1988) after an extraction in $\mathrm{KCl}$ solution [2 M] (Schinner et al. 1996). Total carbon and total nitrogen contents of the soils were measured on a CN analyzer (Truspec CHN Macro, Leco, MI, USA) using oven-dried soil. All physical and chemical soil properties were carried out in triplicates. Important soil properties are summarized in Table 1.

Lab-scale gas measurements

For the lab-scale gas measurements, pots with a diameter of $13 \mathrm{~cm}$ at the top, $9 \mathrm{~cm}$ at the bottom and a height of $11 \mathrm{~cm}$ were used. The pots could be closed with special plastic hoods that were gas-tight after additional taping. For the purpose of drainage, each pot first received $60 \mathrm{~g}$ of polyvinyl chloride pellets. For the $l a b-$ scale gas measurements, soils from grassland and forest study sites (see sites description) were used. Soils were sieved through a 4-mm mesh and $550 \mathrm{~g}$ were added to each pot. Grassland soils were seeded with grassland plants and forest soils were planted with tree seedlings. For the study of grassland plants, two site-specific plants, Poa pratensis and Plantago lanceolata, were grown in the pots from seeds that were obtained from a local seed distributor (Samen Schwarzenberger, Tyrol, Austria). Prior to sowing, the seeds were surface sterilized by washing in calcium hypochlorite [5 \%] for $15 \mathrm{~min}$ for two times, followed by washing with distilled water for three times. Each pot filled with soil from the grassland sites was either sown with Plantago lanceolata or Poa pratensis, 1.5 or $1 \mathrm{~g}$, respectively (about 250 seeds), in six replicates per soil site and plant species leading to 24 pots for both sites. Seedlings were pre-grown in the pots for 5 months at $10-20{ }^{\circ} \mathrm{C}$ (nightday) and $16 \mathrm{~h}$ photoperiod before lab-scale gas measurements started. In case of forest soil, two site-specific trees, Picea abies and Larix decidua, were chosen and used for the lab-scale gas measurements. For plantation, 2 year old seedlings of both were withdrawn from the national forest garden (Landesforstgarten Stams, Tyrol, Austria). Each pot filled with soil from the forest sites was planted with one seedling of $P$. abies or L. decidua in six replicates per soil site and plant species again leading to 24 pots in total and incubated for 6 months.

Gas analyses

Lab-scale gas measurements were performed under atmospheric conditions at 10,25 and $37{ }^{\circ} \mathrm{C}$. For the 


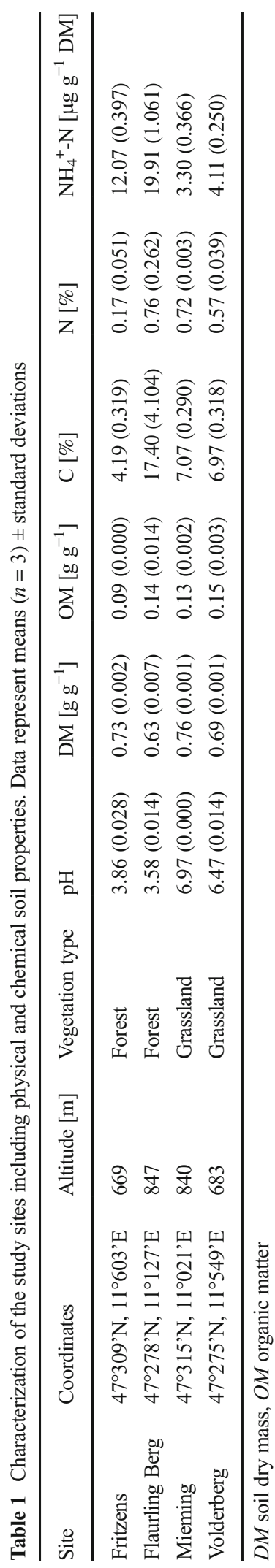

grassland sites, additionally $\mathrm{CH}_{4}$ enriched conditions $[1 \%, v / v]$ were simulated and gas measurements were performed at the aforementioned temperatures in three replicates. Over a time period of several hours, gas samples were taken through inserted septa at the top of the plastic hoods and subsequently analyzed on $\mathrm{CH}_{4}$ and $\mathrm{CO}_{2}$. To determine $\mathrm{CH}_{4}$ flux from soil itself, pots without plant coverage were analyzed in six parallels (three parallels under methane enriched conditions) as well. In all approaches, water content was controlled gravimetrically and kept constant at in situ conditions by rewetting with deionized water. $\mathrm{CH}_{4}$ and $\mathrm{CO}_{2}$ concentrations were determined using a Shimadzu gas chromatograph. The instrument was equipped with a ShinCarbon TS 100/120 mesh $(2 \mathrm{~m} \times 1 \mathrm{~mm})$ column and a flame ionization detector (FID) with methanizer. The FID with methanizer was used for determining $\mathrm{CO}_{2}$ and $\mathrm{CH}_{4}$. The injector and column temperatures were set at $160{ }^{\circ} \mathrm{C}$, the FID at $180{ }^{\circ} \mathrm{C}$ and the methanizer at $380^{\circ} \mathrm{C}$. Nitrogen was used as carrier gas.

DNA extraction

DNA extraction was performed with bulk and rhizosphere soil samples from $25{ }^{\circ} \mathrm{C}$. Bulk soil was collected from pots without plant coverage and rhizosphere soil was collected by shaking the plants in $\mathrm{NaCl}[0.9 \%]$ for $10 \mathrm{~min}$. The obtained soil slurry was centrifuged at $10.000 \mathrm{rpm}$ for $20 \mathrm{~min}$ and the supernatant was discarded. DNA of bulk and rhizosphere soil was extracted using the NucleoSpin ${ }^{\circledR}$ Soil Extraction Kit (Macherey-Nagel) according to the manufacturer's protocol (elution volume $50 \mu \mathrm{l})$. The quality and quantity of the DNA extractions were controlled via UV/VIS spectrophotometry with NanoDrop 2000 c $^{\text {TM }}$ (PeqLab, Germany) and QuantiFluor ${ }^{\circledR}$ dsDNA Dye (Promega, Germany).

PCR amplification and next-generation sequencing

PCR amplification was conducted according to Cruaud et al. (2014) using the PCR Mastermix MyTaq (VWR, Germany) and $0.25 \mathrm{mM}$ (each) primer performing $33 \mathrm{cy}$ cles. PCR reactions were performed with $\sim 10 \mathrm{ng}$ of pooled DNA extracts. Archaea were identified via V5V6 hypervariable region of archaeal 16S rDNA applying the primer pair: Arch2F GGATTAGA TACCCSGGTAGTC and Arch2R GYGGGTCT CGCTCGTTRCC (Cruaud et al. 2014). To allow multiplexing, forward primers were fused to 6 different 
tags (6 nucleotides). Amplicons were sequenced via next-generation sequencing using the Illumina MiSeq platform in a 313-bp paired end approach (GATC Biotech, Konstanz, Germany). Bioinformatics were performed with the MOTHUR v.1.35.1 software pipeline (64 bit executionable) according to Standard Operating Procedure for MiSeq (Kozich et al. 2013). Stringent filtering steps including screening and trimming were performed in order to remove all the ambiguous reads and sequences longer than $400 \mathrm{bp}$. After the alignment of the unique sequences against the SILVA rRNA gene database, all putative chimeric sequences were detected and removed by performing the Uchime chimera detection program (Edgar et al. 2011). The sequencing noise due to sequencing errors was reduced by pre-clustering at $3 \%$. Taxonomic classification was carried out using the Bayesian classifier implemented in MOTHUR based on the Ribosomal Database Project (RDP) classifier (Cole et al. 2009). Operational taxonomic units (OTUs) were binned at $97 \%$ identity. The number of sequences included in the analysis of Archaea was based on the lowest number of sequences found in all samples. The sequences obtained in this study have been submitted to the NCBI Sequence Read Archive (SRA) under the SRA accession number SRP064407.

\section{Quantitative PCR (qPCR)}

Quantitative PCR was conducted using the SensiFast $^{\mathrm{TM}}$ SYBR No-Rox Kit (Bioline, UK) on a Corbett Life Science Rotor-Gene ${ }^{\mathrm{TM}} \mathrm{Q}$ system (Qiagen, Netherlands). Methanotrophic Bacteria were quantified using the primer pair $189 \mathrm{f}$ and mb661r targeting the pmoA gene (Kolb et al. 2003). qPCR was performed with bulk and rhizosphere soil in three replicates each. qPCR reactions $(20 \mu \mathrm{l})$ contained $10 \mu \mathrm{l}$ SensiFast ${ }^{\mathrm{TM}}$ SYBR No-Rox Kit (Bioline, UK), $0.2 \mu \mathrm{M}$ of each primer, $5 \mathrm{mM} \mathrm{MgCl}_{2}$, $0.04 \%(v / v)$ bovine serum albumin, and $2 \mathrm{ng}$ of DNA template. qPCR was preceded by an initial denaturation step of $5 \mathrm{~min}$ at $95{ }^{\circ} \mathrm{C}$, followed by $25 \mathrm{~s}$ at $95^{\circ} \mathrm{C}, 25 \mathrm{~s}$ at $63^{\circ} \mathrm{C}$ and $20 \mathrm{~s}$ at $72{ }^{\circ} \mathrm{C}$. In the run, we included non-template DNA and non-template controls (UltraPure DNase/RNase Free Distilled Water, Invitrogen, USA). Pure culture DNA for preparation of genomic DNA standards and construction of the calibration curves were extracted from Methylobacter tundripaludum (DSM No. 17260).
Statistical data treatment

Statistical analyses regarding gas measurements were carried out using Statistica 9.0 (StatSoft®). The influence of temperature on gas fluxes was calculated via repeated-measures ANOVA. For the calculation of net $\mathrm{CH}_{4}$ flux rates for all approaches the delta $\mathrm{CH}_{4}$ concentration between start time concentration and concentration after $24 \mathrm{~h}$ was taken into account in order to allow the comparison of bedrock, vegetation type, temperature, and plant species. Significant differences were ascertained by one-way, main effect or multifactorial ANOVA. A significance level of 0.05 was used to assess differences between treatments. Fisher's Least Significant Differences Test was used to discriminate between single variants. Differences between proportions of OTUs were calculated using z-score test.

\section{Results}

$\mathrm{CH}_{4}$ flux at different temperatures with and without plants

Figure 1 summarizes methane concentrations from all variants with and without plant coverage and from both bedrocks resulting in partially great standard deviations. Irrespective of plant species and vegetation types, a highly significant influence of temperature on net $\mathrm{CH}_{4}$ concentrations from upland soils under atmospheric $\mathrm{CH}_{4}$ conditions could be established (***P<0.001). In all approaches, $\mathrm{CH}_{4}$ concentration dropped below the ambient starting point (1.8 ppm). At $25^{\circ} \mathrm{C}$ ambient $\mathrm{CH}_{4}$ concentration decreased below detection level $(0.1 \mathrm{ppm})$ within $48 \mathrm{~h}$, thus, the most pronounced $\mathrm{CH}_{4}$ net consumption was detected at $25{ }^{\circ} \mathrm{C}$ followed by 37 and $10^{\circ} \mathrm{C}$ (Fig. 1). Notably, with increasing incubation time at $37^{\circ} \mathrm{C}$ a remarkable increase in return from a low $\mathrm{CH}_{4}$ concentration to a mean of $1.2 \mathrm{ppm}$ was detected which was not the case at 10 and $25^{\circ} \mathrm{C}$ (Fig. 1).

$\mathrm{CH}_{4}$ flux rates above forest and grassland soils covered with and without site-typical plants

Data demonstrate a significant influence of plants compared to uncovered soil and influences of plants on net $\mathrm{CH}_{4}$ flux were temperature- and site-dependent (Fig. 2, Table S1 and S2 in supplementary material). Overall, $\mathrm{CH}_{4}$ fluxes from soils were significantly different 
Fig. 1 Methane depletion [ppm] above soil at 10,25 and $37^{\circ} \mathrm{C}$. Symbols show means $(n=72) \pm$ standard deviations of all experiments, with and without plants, and on different bedrock types

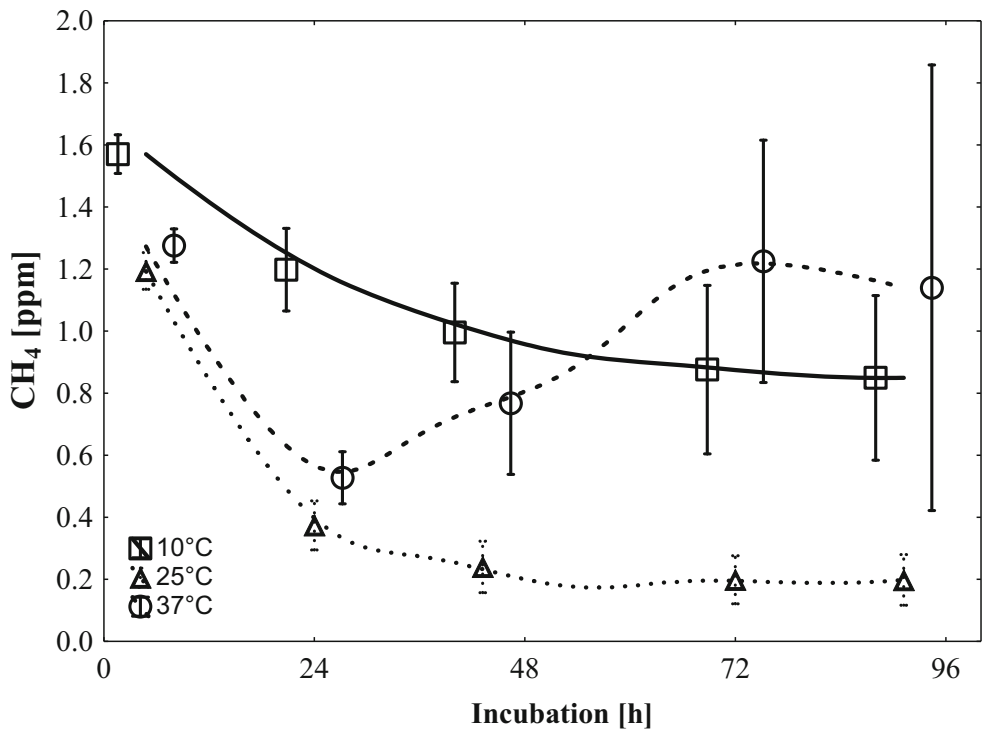

regarding bedrock with soil from limestone revealing a more negative methane balance $\left(-263 \mathrm{nmol} \mathrm{m}^{-2} \mathrm{~h}^{-1}\right)$ compared to siliceous bedrock $\left(-209 \mathrm{nmol} \mathrm{m}^{-2} \mathrm{~h}^{-1}\right)$ including data from both vegetation types (grassland and forest), all plant species, and temperatures $(* * * P<0.001)$. Furthermore, $\mathrm{CH}_{4}$ flux rates without plant coverage showed a distinct more negative $\mathrm{CH}_{4}$ balance $\left(-140 \mathrm{nmol} \mathrm{m}^{-2} \mathrm{~h}^{-1}\right)$ in case of forest soils than in case of grasslands $\left( \pm 0 \mathrm{nmol} \mathrm{m}{ }^{-2} \mathrm{~h}^{-1}\right)$ at $10^{\circ} \mathrm{C}$, which confirms our in-situ flux measurements performed on an average temperature of $13{ }^{\circ} \mathrm{C}$ (data not shown). Regarding flux measurements on grassland sites, $\mathrm{CH}_{4}$ balances were more negative with increasing temperature although the difference between 25 and $37{ }^{\circ} \mathrm{C}$ was not significant. Incubation temperature had also a distinct impact on the way plants affected $\mathrm{CH}_{4}$ flux rates (Table $\mathrm{S} 1$, supplementary material). In case of grassland sites at $10{ }^{\circ} \mathrm{C}$, no significant impact of plants on $\mathrm{CH}_{4}$ balance could be detected (Fig. 2a). Both plant species, P. lanceolata and P. pratensis, increased the capacity of grassland soils to consume $\mathrm{CH}_{4}$ albeit not significantly. Contrary, at $25{ }^{\circ} \mathrm{C}$ grassland sites revealed that plants had a significant influence on net $\mathrm{CH}_{4}$ fluxes compared to uncovered soil (Fig. 2b) and that there was a significant difference between the investigated plant species. In both cases plants attenuated the consumption performance of grassland soils and especially P. pratensis increased the net $\mathrm{CH}_{4}$ balance of grassland soils tremendously from a mean negative methane balance of $-406 \mathrm{nmol} \mathrm{m}^{-2} \mathrm{~h}^{-1}$ in case of uncovered soil to $-150 \mathrm{nmol} \mathrm{m}^{-2} \mathrm{~h}^{-1}$. P. lanceolata also significantly increased net $\mathrm{CH}_{4}$ balance -although to a lesser extent. Thus, results show that at $25{ }^{\circ} \mathrm{C}$ uncovered grassland soil revealed the greatest potential to oxidize and/or the lowest capacity to produce $\mathrm{CH}_{4}$. At $37^{\circ} \mathrm{C}$ mean net $\mathrm{CH}_{4}$ balance within $24 \mathrm{~h}$ was very low $\left(-408 \mathrm{nmol} \mathrm{m}^{-2} \mathrm{~h}^{-1}\right)$ above the uncovered soil which is very similar to the balance determined at $25{ }^{\circ} \mathrm{C}$ (Fig. 2c). At $37^{\circ} \mathrm{C}$ plant coverage again showed a significant influence on net $\mathrm{CH}_{4}$ balances with significant different impacts depending on plant species. Again, in case of $P$. pratensis mean net $\mathrm{CH}_{4}$ balance was increased but in case of P. lanceolata mean net $\mathrm{CH}_{4}$ balance was decreased in comparison to soil without plant coverage (Fig. 2c). Overall, net $\mathrm{CH}_{4}$ balances above grassland soils were significantly lower with increasing temperature.

Above forest soils temperature had a significant influence on $\mathrm{CH}_{4}$ fluxes as well although overall the consumption rates were less pronounced compared to that determined in grassland soils and reached most negative $\mathrm{CH}_{4}$ balances at $25^{\circ} \mathrm{C}$ (Fig. 2d-f, Table $\mathrm{S} 2$ in supplementary material). Our data proved a clear influence of temperature on net $\mathrm{CH}_{4}$ flux and revealed clear differences between covered and uncovered soil, especially at 10 and $37^{\circ} \mathrm{C}$. At $10^{\circ} \mathrm{C} \mathrm{L}$. decidua significantly increased consumption rates compared to uncovered soil (Fig. 2d). $\mathrm{CH}_{4}$ flux from uncovered soils was $-125 \mathrm{nmol} \mathrm{m}^{-2} \mathrm{~h}^{-1}$ and decreased by nearly 2.5 times mediated by $L$. decidua and reached therefore $-285 \mathrm{nmol} \mathrm{m}{ }^{-2} \mathrm{~h}^{-1}$. P. abies triggered the net consumption of $\mathrm{CH}_{4}$ as well but to a much lesser extent (Fig. 2d). At $25{ }^{\circ} \mathrm{C}$ the differences in net $\mathrm{CH}_{4}$ balances between 

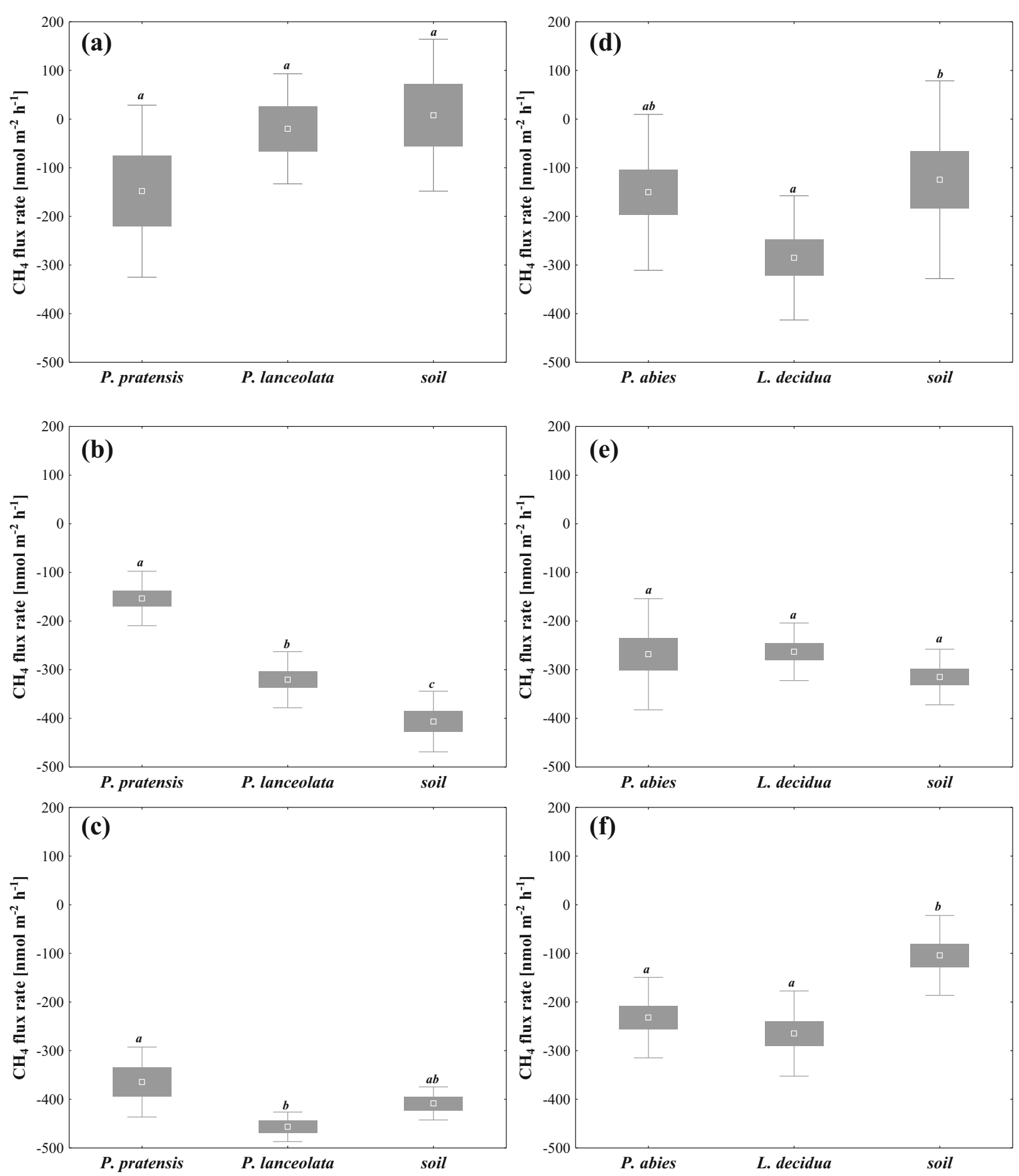

Fig. 2 Methane flux rates [nmol m $\mathrm{m}^{-2} \mathrm{~h}^{-1}$ ] above grassland soil with and without $P$. pratensis or $P$. lanceolata (left panel) and forest soil with and without $P$. abies or $L$. decidua (right panel) at (a,d) $10{ }^{\circ} \mathrm{C}$, (b,e) $25^{\circ} \mathrm{C}$ and $(\mathbf{c}, \mathbf{f}) 37^{\circ} \mathrm{C}$ including data from both

bedrock types. The boxes show means \pm SE $(n=12)$, the spreads depict SD. Significant differences $(P<0.05)$ between groups are indicated by different letters

both, uncovered soil and planted soils and between the In contrast, differences in net $\mathrm{CH}_{4}$ balances were signifinvestigated plant species were not significant (Fig. 2e). icant again at $37{ }^{\circ} \mathrm{C}$ and at this temperature both tree 
species significantly decreased net $\mathrm{CH}_{4}$ balances by a factor of 2 to 2.5 (Fig. 2f). As for grassland soils, again temperature had a significant influence on the way plants affected $\mathrm{CH}_{4}$ fluxes (Table $\mathrm{S} 2$, supplementary material). In general and summarizing all data including all temperatures and both bedrock types, the impact of plants on $\mathrm{CH}_{4}$ fluxes compared to uncovered soils distinctly differed depending on vegetation type (Fig. 3). The two forest trees studied in this investigation increased the consumption capacity of forest soils leading to a decreased $\mathrm{CH}_{4}$ balance compared to pure soil $\left(-55 \mathrm{nmol} \mathrm{m}{ }^{-2} \mathrm{~h}^{-1}\right)$ while grassland plants increased $\mathrm{CH}_{4}$ balance compared to uncovered soil $\left(+54 \mathrm{nmol} \mathrm{m}^{-2} \mathrm{~h}^{-1}\right)$ (Fig. 3).

$\mathrm{CH}_{4}$ flux rates above grassland soils under $\mathrm{CH}_{4}$ enriched conditions

Under $\mathrm{CH}_{4}$ enriched conditions, temperature significantly influenced net $\mathrm{CH}_{4}$ measurements $(* * * P<0.001)$ and so the effect of temperature was similar to that determined with $\mathrm{CH}_{4}$ fluxes under ambient $\mathrm{CH}_{4}$ concentrations. In all approaches, net $\mathrm{CH}_{4}$ fluxes were negative and most negative $\mathrm{CH}_{4}$ balances were reached at $25{ }^{\circ} \mathrm{C}$, followed by 37 and $10{ }^{\circ} \mathrm{C}$. At $10{ }^{\circ} \mathrm{C}$ little changes in the enriched $\mathrm{CH}_{4}$ concentrations were measured and no significant influence of plant coverage was detected. At $37{ }^{\circ} \mathrm{C} \mathrm{CH}_{4}$ flux was more negative compared to $10{ }^{\circ} \mathrm{C}$ and again plants did not significantly influence $\mathrm{CH}_{4}$ flux rates. But similar to measurements at ambient $\mathrm{CH}_{4}$ concentrations, plant coverage significantly reduced the consumption capacity of grassland soils at $25{ }^{\circ} \mathrm{C}$ compared to uncovered soil $(* P<0.05)$ but the species-specific difference could not be discerned anymore (Fig. S1, supplementary material). Furthermore, bedrock type did not influence net $\mathrm{CH}_{4}$ balance at elevated $\mathrm{CH}_{4}$ concentrations significantly.

Next-generation sequencing-derived archaeal community composition

Unfortunately, DNA extraction and amplification of rhizosphere samples of tree seedlings did not lead to reliable results and were thus omitted. In case of grassland plants a total of 765,753 sequences reads for $A r$ chaea were obtained from Illumina sequencing. After initial quality processing and denoizing, 26,030 archaeal sequences were included in OTU analysis. Of these sequences, $68.61 \%$ could be classified into the Euryarchaeota phylum while $12.78 \%$ belonged to Crenarchaeota and Thaumarchaeota and $18.61 \%$ were assigned as unclassified Archaea. Crenarchaeota and Thaumarchaeota were combined to the lately suggested superphylum Proteoarchaeota (Petitjean et al. 2014) including Diapherotrites and Pacearchaeota in this case as well. OTU assignment at $97 \%$ identity level resulted in 2478 OTUs. For downstream analysis and to compare archaeal community structure in bulk and rhizosphere soils from both grassland sites, sequences in each
Fig. 3 Delta methane flux rates $\left[\mathrm{nmol} \mathrm{m}{ }^{-2} \mathrm{~h}^{-1}\right.$ ] between covered and uncovered soil showing the sole effect of plants depending on vegetation type including data from all temperatures and both bedrock types with $n=72$ for each vegetation type

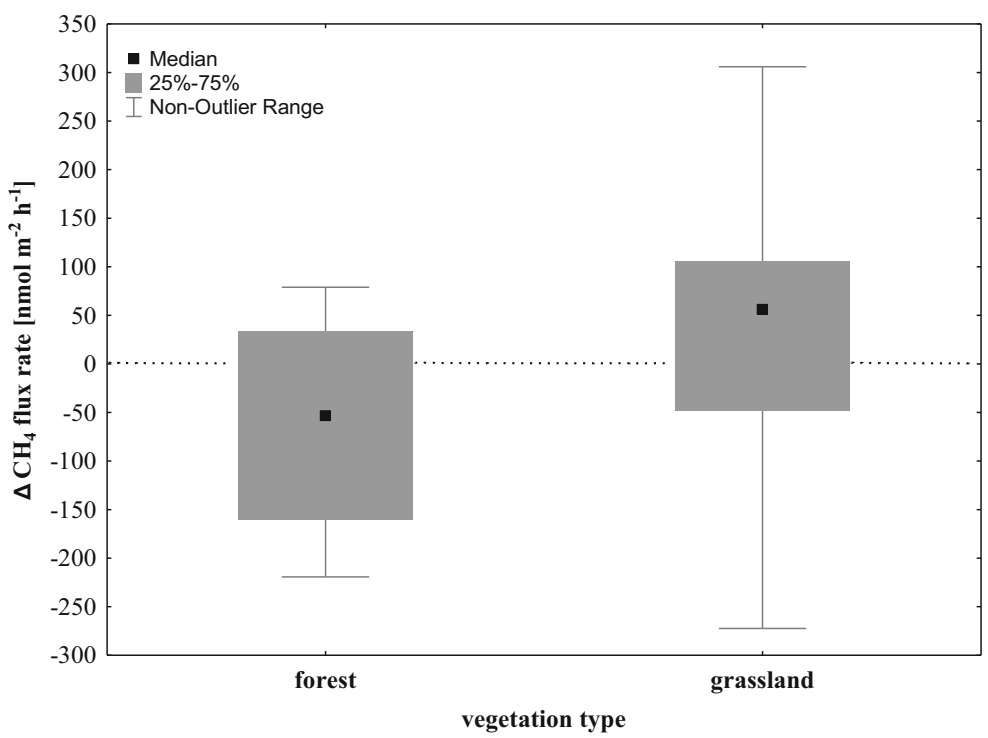


sample were reduced to 1409 reads which was the smallest number of sequences in any of the six samples. Coverage values between 0.86 and 0.90 were obtained, indicating between 86 and $90 \%$ species detection rates. OTUs representing less than $0.10 \%$ of the relative abundance were clustered as were OTUs at the same genus level. Archaeal community analysis revealed clear differences within the community composition of the investigated soils (Fig. 4). Differences within the archaeal community were primarily caused by the two different soil sites, followed by the influence of the plants. Plant species led to different archaeal community shifts within the respective rhizospheres, with distinctly greater changes on siliceous bedrock. NGS showed a dominance of Methanosarcina sp. on silicate and Methanosaeta sp. on limestone. The proportion of Euryarchaeota increased within the rhizosphere soil of the plants whereas Proteoarchaeota decreased. On silicate bedrock, Methanosarcina sp., Methanosaeta sp., Methanobacterium sp., and Methanoculleus sp. significantly increased within the rhizosphere fraction of the two investigated grasses compared to bulk soil whereas the proportion of unclassified Proteoarchaeota distinctly decreased. The increase in abundance of Methanosarcina sp. was significantly more pronounced in the rhizosphere of $P$. lanceolata. On limestone
Methanobacterium sp. became significantly and Methanosaeta sp. became slightly $(p=0.052)$ more dominant in the rhizosphere of the investigated grassland plants than in bulk soils.

Abundance of methanotrophs in grassland soils

In the current study, qPCR was used to quantify the methanotrophic pmoA gene copies in bulk and rhizosphere soil samples of the grassland study sites. Only a small variation in $p m o A$ gene copy numbers was found in the studied grassland soil samples, ranging from $3.87 \times 10^{7}$ and $1.61 \times 10^{8}$ copies per gram dry soil. Thus, no significant difference in methanotrophic abundances was found between soils from bulk and rhizosphere, irrespective of plant species and bedrock type.

\section{Discussion}

In this study, we examined the impact of (1) temperature, (2) bedrock, (3) vegetation type, and (4) plants on net methane flux of upland soils. Our results showed that soils, regardless of vegetation type, were a net sink for $\mathrm{CH}_{4}$, but under certain conditions $\mathrm{CH}_{4}$ production could be observed as well and that the consumption

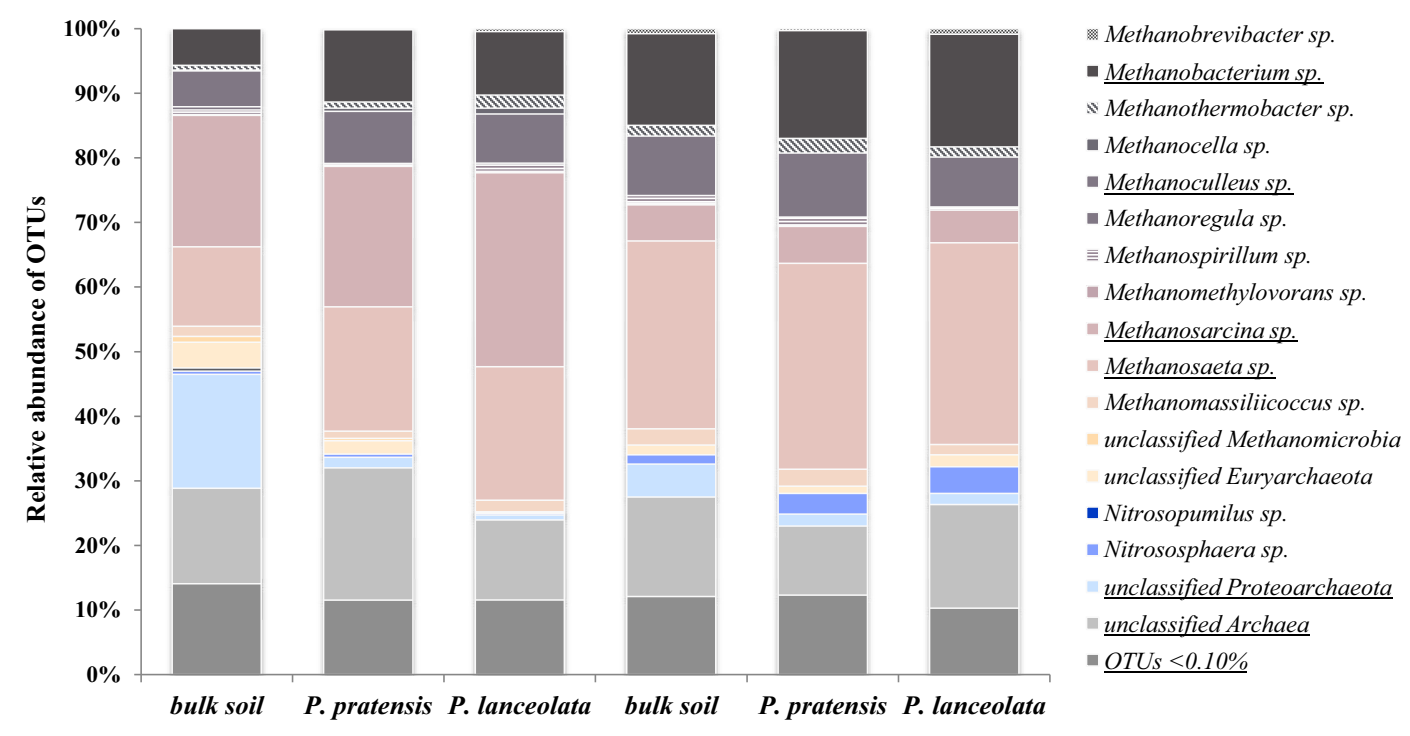

silicate bedrock

Fig. 4 Relative abundance [\%] of archaeal OTUs classified on genus level within bulk and rhizosphere soil of $P$. pratensis or $P$. lanceolata on silicate and limestone bedrock analyzed via MiSeq Illumina sequencing. OTUs $<0.10 \%$ were summarized and OTUs

\section{limestone bedrock}

not classifiable on genus level were combined according to the taxon level specified. OTUs accounting for more than $5 \%$ in at least one sample are underlined 
capacity of soils varied according to temperature and plant coverage. In the context of changing climate conditions, possible impacts of temperature increase are intensively discussed (Gobiet et al. 2014; Thornton et al. 2014). In relation to the global relevance of the greenhouse gas methane an important question is whether and how $\mathrm{CH}_{4}$ dynamics in soils are influenced by abiotic and biotic parameters, e.g., warming and land use (Bodelier and Steenbergh 2014; Tate 2015). Due to the huge area of upland soils, even very low methane flux rates will become relevant and detailed information about the influence of plants on methane fluxes could contribute to future climate models.

In our study, temperature had a significant effect on net methane balance above grassland soils leading to considerable consumption rates while the effect was less pronounced above forest soils. In case of grassland soils, net methane balances were more negative at increasing temperature, regardless of plant species and bedrock which might be caused by the fact that grassland soils are generally faced with higher temperature fluctuations compared to forest soils. Of course, the highest of the three temperatures tested (i.e. $37^{\circ} \mathrm{C}$ ) within the present investigation does not represent standard soil temperatures but might be possible in soils under certain conditions as especially the upper soil layers easily heat up in summer and can reach high temperatures (Song et al. 2013). A further idea behind applying higher temperatures was to reach a temperature range more suitable for methanogens (Le Mer and Roger 2001) and -in combination with psychrophilic and mesophilic temperatures- to investigate quite great temperature steps which should indicate the direction of temperature caused effects.

In all approaches, methane concentrations dropped below its initial value and increasing temperature additionally increased the consumption of ambient methane which on the first glimpse suggests that increasing temperatures might even attenuate $\mathrm{CH}_{4}$ efflux. Abundance and activity of methanogens and methanotrophs are known to be controlled by temperature, as well as other edaphic factors, such as soil moisture, $\mathrm{pH}$, ammonium, organic matter, and vegetation types (Dunfield 2007; Kolb 2009; Le Mer and Roger 2001; Mohanty et al. 2007). While both types of microorganisms show growth over a wide temperature range, methanogens have a temperature optimum at higher temperatures $\left(>30^{\circ} \mathrm{C}\right)$ and low soil temperatures reduce $\mathrm{CH}_{4}$ production (Le Mer and Roger 2001). Low soil temperatures reduce $\mathrm{CH}_{4}$ production by decreasing the activity methanogens itself and additionally the associated microorganisms engaged in producing substrates for methanogens (Le Mer and Roger 2001). In contrast, most methanotrophs are neutrophilic and mesophilic, but psychrophilic, mesophilic and thermophilic species have been described as well (Nazaries et al. 2013; Op den Camp et al. 2009; Trotsenko and Khmelenina 2005). Comparable little changes in methane concentrations at $10{ }^{\circ} \mathrm{C}$ over time may be related to decreased overall metabolic activity and limited soil-borne methane availability might additionally reduce methanotrophic activities. At $25{ }^{\circ} \mathrm{C}$ metabolic activities increased and led to a sharp decrease of methane concentrations within several hours. Soil methane uptake rates increase with increasing soil temperature due to temperature-dependent enzymatic processes (ButterbachBahl and Papen 2002; Luo et al. 2013; Steinkamp et al. 2001). However, the response of soil methane oxidation to temperature is not only controlled by enzyme-based activity but also by the transport of methane in the gas phase and the exchange with soil water (King and Adamsen 1992). Sensitivity of soil methane consumption to temperature reflects a combination of microbial activities, population densities of methanotrophs, gas-phase methane concentrations, and soil water content (Henckel et al. 2000; King and Adamsen 1992). Previous studies showed that temperature effects on methane oxidation may be more pronounced at lower temperatures $<15^{\circ} \mathrm{C}$ (Steinkamp et al. 2001). This might explain why methane exchange rates are only slightly increased at $37^{\circ} \mathrm{C}$ compared to $25^{\circ} \mathrm{C}$. It is important to keep in mind that using this method we were not able to separate methanogenesis and methane oxidation and thus, the methane flux observed has to be considered as a difference between production and consumption. Due to general increased metabolic activities, oxygen consumption increases as well and probably enhances anaerobic micro-niches within soils. Thus, although the gas solubility within soil water decreases with increasing temperature, increased methanogenesis might substitute the loss and lead to an increased methane exchange in the end. Due to long generation times of methanogens and/or increased turnover in the microbial communities, the activity of methanogens started again to increase after a rather long lag period (Fig. 1), however, this secondarily increased $\mathrm{CH}_{4}$ production at high temperatures clearly points to the correlation between $\mathrm{CH}_{4}$ efflux and temperature.

In our lab-scale flux measurements we could show that methane balances of uncovered soils were distinctly more negative on grassland than on forest sites. Soil 
moisture was repeatedly shown to be an important factor influencing methane uptake rates of upland soils (Luo et al. 2013; Schaufler et al. 2010). The study sites in this investigation had quite comparable soil moisture contents and thus the differences in net methane balances could not be traced back to this impact. Further, it seems natural to consider higher $\mathrm{pH}$ values within grassland soils to be responsible for higher methane uptake rates as the overall metabolic activity is increased on grassland sites. Indeed, $\mathrm{pH}$ is a governing factor for the distribution of methanotrophic communities and coinfluences their life strategies enabling subgroups of methanotrophs to predominate under different conditions (Ho et al. 2013). Contrary to this, another recent investigation described that soil $\mathrm{pH}$ does not seem to be strong controller of $\mathrm{CH}_{4}$ oxidation since comparable methanotrophic activities were found over broad range of pH values (Kolb 2009; Nazaries et al. 2013) pointing out the necessity of further studies investigating the effects of $\mathrm{pH}$ on $\mathrm{CH}_{4}$ oxidation. However, also an inhibition of methanogens has to be considered as methane fluxes give the difference between $\mathrm{CH}_{4}$ consumption and production. Most known methanogens grow optimally at near-neutral pH (Le Mer and Roger 2001; Mutschlechner et al. 2015) which would suggest a malfunction of methanogenesis in our studied forest soils but Schleper et al. (2005) showed that Euryarchaeota have a strong ability to adapt to low-pH stress, albeit diversity might be reduced (Hu et al. 2013).

The impact of plants on net methane fluxes was different depending on temperature, vegetation type, plant species, and bedrock. Whereas in case of grasslands and including all experiments, net methane flux rates were most negative without vegetation, forest soils' net flux rates were lower when covered with plants. Our study pointed out that grassland plants were able to increase $\mathrm{CH}_{4}$ balance compared to uncovered soil whereas forest trees decreased $\mathrm{CH}_{4}$ balance (Fig. 3, Table 2). Especially pots with $L$. decidua did significantly increase the oxidation capacity and/or reduced methanogenesis in forest soils. Karbin et al. (2015) also showed that forest soils under $L$. decidua had a higher $\mathrm{CH}_{4}$ oxidation capacity compared with other trees (Pinus uncinata). In their study, they suggested that this effect may be due to less-terpene containing needles compared to Pinus needles as terpenes are known to inhibit the activity of methanotrophic Bacteria (Amaral et al. 1998; Karbin et al. 2015). In our case we cannot trace this effect back to litter as the soils used for our lab-
Table 2 Average and rounded alterations of $\mathrm{CH}_{4}$ flux rates $\left[\mathrm{nmol} \mathrm{m}{ }^{-2} \mathrm{~h}^{-1}\right.$ ] through plant species compared to the respective uncovered soil. Data include all temperatures and both bedrock types with $\mathrm{n}=36$ for each plant species

\begin{tabular}{ll}
\hline Plant species & $\mathrm{CH}_{4}$ flux $\left[\mathrm{nmol} \mathrm{m}^{-2} \mathrm{~h}^{-1}\right]$ \\
\hline P. abies & -35 \\
L. decidua & -90 \\
P. pratensis & +55 \\
P. lanceolata & +10 \\
\hline
\end{tabular}

scale gas measurements did not contain any needles. We suggest that it is more likely that the species effect may be caused by plant physiology or by composition, quality and quantity of root exudates and detritus which could have in return influenced the abundance and activity of both, methanotrophic and methanogenic microorganisms. Several tracer studies have shown that photosynthesis of plants and methanogenesis might be tightly coupled (King and Reeburgh 2002; Megonigal et al. 2004; Ström et al. 2005) thus pointing to the importance of root exudates. In a study by Ström et al. (2003) it was shown that photosynthetic rates influenced the availability of acetate and thus in return the formation of $\mathrm{CH}_{4}$. These results originate from investigations about wetland plants but it is reasonable that similar relationships do exist in well-aerated soils as well.

Lab-scale gas measurements were repeated for grassland sites under methane enriched conditions $(1 \% \mathrm{v} / \mathrm{v})$. The rationale of applying higher methane concentrations is that in previous studies it was shown that methane production potentials reached up to $1 \% \mathrm{CH}_{4}$ (Hofmann et al. 2016; Praeg et al. 2014; Wagner et al. 2012). Thus, it was of our interest to study whether the influences of temperature, plants, and bedrock type on net methane balance are changed or remain under elevated methane concentrations. It was shown that under methane enriched conditions again temperature was a crucial parameter that significantly influenced net methane balances reaching the most negative mean methane balance at $25^{\circ} \mathrm{C}$. Results were similar to those derived under ambient $\mathrm{CH}_{4}$ concentrations and showed that high $\mathrm{CH}_{4}$ concentrations which might be present in anaerobic microhabitats of soils led to comparable, yet not identical results. Under ambient methane concentration grassland plant species differed in how they influenced $\mathrm{CH}_{4}$ flux. This species-related difference was not observed any longer under methane enriched conditions. Thus, 
the importance of plant species for $\mathrm{CH}_{4}$ flux in arable soils might decrease with increased $\mathrm{CH}_{4}$ concentration.

One special issue of our investigation was to outline the influence of plants on $\mathrm{CH}_{4}$ flux. Although causal interrelationships between plants and microorganisms engaged in $\mathrm{CH}_{4}$ cycle are not clear so far, our results point to possibilities of counteracting $\mathrm{CH}_{4}$ emissions through different plant species and land use systems. Overall, temperature was a central factor that influenced methane fluxes significantly and altered the effect of plants. The lack of consistency in these findings that some species increased the consumption potential while others led to a decrease and the combination with varying effects of temperature emphasizes the importance of vegetation type and plant species for $\mathrm{CH}_{4}$ emission from well-aerated soils.

Restults of Illumina MiSeq sequencing of the archaeal 16S rRNA genes revealed that archaeal community structure differed between the two investigated grassland sites. Samples from soil roots of tree species did not lead to reliable results, possibly because too less soil adhered to the roots, and data were thus omitted and the following description of archaeal community composition refers to grassland roots only. Our data demonstrated a difference between the sites and also between bulk soil and rhizosphere soil of the investigated grassland plants. Archaeal community structure within the rhizosphere was shifted to a higher abundance of Euryarchaeota while the proportion of Proteoarchaeota decreased. This rhizosphere effect was more pronounced on siliceous bedrock than on limestone. Consequently, the effect of soil dominates on limestone while the influence of the fractions prevailed on soil from silicate bedrock. As the changes within the abundances of Archaea in fractions and sites do not give any information about the activity, the interpretation in combination with the gas measurement results is hardly possible. Nevertheless, the higher proportion of methane-producing Euryarchaeota corresponds with the significant higher methane balance at $25^{\circ} \mathrm{C}$ of soils covered with $P$. lanceolata or $P$. pratensis compared to uncovered soil. qPCR results indicated that regardless of bedrock type, plant species, and soil fraction the abundance of methanotrophic microorganisms was similar in all grassland samples. Our results show that methanotrophic bacteria are important members of the soil community, present in numbers of about $10^{7}$ to $10^{8}$ pmoA gene copies per gram dry weight of soil. The measured abundance is comparable to population sizes of methanotrophs found in other upland soils ranging from $10^{5}$ to $10^{7}$ cells per gram dry weight of soil (Willison et al. 1997; Horz et al. 2002). qPCR results and the measured methane fluxes emphasize that methanotrophs are apparently of ecological relevance concerning $\mathrm{CH}_{4}$ uptake. We hypothesize that the different net-methane balances could thus either be traced back to the abundance and activity of methanogens and/or different cell-specific methanotrophic activities.

So far, the influence of different plants on methane fluxes out of well-aerated soils at different temperatures has not been studied in detail and thus knowledge is really limited. In summary, we could show a distinct impact of plants on $\mathrm{CH}_{4}$ flux and also that this influence cannot be attributed to a single driver. Generally the multifactorial analyses revealed a great complexity of $\mathrm{CH}_{4}$ cycle and the difficulty to pinpoint a general valid relationship between $\mathrm{CH}_{4}$ flux and abiotic and biotic influencing parameters. Results highlight that $\mathrm{CH}_{4}$ cycle is altered depending on plant species, vegetation type, and temperature. Our data give a first insight in how (i) plants alter methane flux of upland soils, (ii) possible temperature changes in these environments might influence $\mathrm{CH}_{4}$ flux depending on vegetation type and (iii) archaeal community structure differs between bulk and rhizosphere soil and between two species of grassland plants. We propose that plant-induced changes in root exudates may be responsible for the different effects of plants on $\mathrm{CH}_{4}$ flux rates of well-aerated soils as previously shown for wetlands (Ström et al. 2003; Ström et al. 2012). Overall, the study is a step towards determining the influence of plants on methane flux of well-aerated soils and emphasizes - in the context of the global relevance of the greenhouse gas methane - the need to better resolve impacts of abiotic and biotic parameters on methane cycle in upland soils.

Acknowledgments Open access funding provided by University of Innsbruck and Medical University of Innsbruck. This work was supported by the Tyrolean Science Fund (TWF, 0404/1453) and the doctoral grant of the University of Innsbruck.

Open Access This article is distributed under the terms of the Creative Commons Attribution 4.0 International License (http:// creativecommons.org/licenses/by/4.0/), which permits unrestricted use, distribution, and reproduction in any medium, provided you give appropriate credit to the original author(s) and the source, provide a link to the Creative Commons license, and indicate if changes were made. 


\section{References}

Amaral JA, Ekins A, Richards SR, Knowles R (1998) Effect of Selected Monoterpenes on Methane Oxidation, Denitrification, and Aerobic Metabolism by Bacteria in Pure Culture. Appl Environ Microbiol 64:520-525

Angel R, Matthies D, Conrad R (2011) Activation of methanogenesis in arid biological soil crusts despite the presence of oxygen. PLoS One 6:1-8

Angel R, Claus P, Conrad R (2012) Methanogenic archaea are globally ubiquitous in aerated soils and become active under wet anoxic conditions. ISME J 6:847-862

Bodelier PLE, Steenbergh AK (2014) Interactions between methane and the nitrogen cycle in light of climate change. Curr Opin Environ Sustain 9-10:26-36

Butterbach-Bahl K, Papen H (2002) Four years continuous record of $\mathrm{CH}_{4}$-exchange between the atmosphere and untreated and limed soil of a N-saturated spruce and beech forest ecosystem in Germany. Plant Soil 240:77-90

Cole JR, Wang Q, Cardenas E, Fish J, Chai B, Farris RJ, KulamSyed-Mohideen AS, McGarrell DM, Marsh T, Garrity GM, Tiedje JM (2009) The Ribosomal Database Project: improved alignments and new tools for rRNA analysis. Nucleic Acids Res 37:141-145

Conrad R (2009) The global methane cycle: recent advances in understanding the microbial processes involved. Environ Microbiol Rep 1:285-292

Cruaud P, Vigneron A, Lucchetti-Miganeh C, Ciron PE, Godfroy A, Cambon-Bonavita M-A (2014) Influence of DNA Extraction Method, 16S rRNA Targeted Hypervariable Regions, and Sample Origin on Microbial Diversity Detected by 454 Pyrosequencing in Marine Chemosynthetic Ecosystems. Appl Environ Microbiol 80: 4626-4639

Dlugokencky EJ, Masarie KA, Lang PM, Tans PP (1998) Continuing decline in the growth rate of the atmospheric methane burden. Nature 393:447-450

Dunfield PF (2007) Green House Gas Sinks. In: Reay DS, Hewitt CN, Smith KA, Grace J (eds) The soil methane sink. CABI, Wallingford, UK, pp. 152-170

Edgar RC, Haas BJ, Clemente JC, Quince C, Knight R (2011) UCHIME improves sensitivity and speed of chimera detection. Bioinformatics 27:2194-2200

Ferry JG (2010) The chemical biology of methanogenesis. Planet Space Sci 58:1775-1783

Gobiet A, Kotlarski S, Beniston M, Heinrich G, Rajczak J, Stoffel M (2014) Twenty-first century climate change in the European Alps - A review. Sci Total Environ 493:1138-1151

Hanson RS, Hanson TE (1996) Methanotrophic bacteria. Microbiol Rev 60:439-471

Henckel T, Jäckel U, Schnell S, Conrad R (2000) Molecular analyses of novel methanotrophic communities in forest soil that oxidize atmospheric methane. Appl Environ Microbiol 60:1801-1808

Ho A, Kerckhof F-M, Luke C, Reim A, Krause S, Boon N, Bodelier PLE (2013) Conceptualizing functional traits and ecological characteristics of methane-oxidizing bacteria as life strategies. Environ Microbiol Rep 5:335-345

Ho A, Reim A, Kim SY, Meima-Franke M, Termorshuizen A, De Boer W, van der Putten WH, Bodelier PLE (2015)
Unexpected stimulation of soil methane uptake as emergent property of agricultural soils following bio-based residue application. Glob Chang Biol 21:3864-3879

Hofmann K, Praeg N, Mutschlechner M, Wagner AO, Illmer P (2016) Abundance and potential metabolic activity of methanogens in well-aerated forest and grasland soils of an alpine region. FEMS Microbiol Ecol 92(2). doi:10.1093/ femsec/fiv171

Horz HP, Raghubanshi AS, Heyer E, Kammann C, Conrad R, Dunfield PF (2002) Activity and community structure of methane-oxidising bacteria in a wet meadow soil. FEMS Microbiol Ecol 41:247-257

Hu H-W, Zhang L-M, Yuan C-L, He J-Z (2013) Contrasting Euryarchaeota communities between upland and paddy soils exhibited similar $\mathrm{pH}$-impacted biogeographic patterns. Soil Biol Biochem 64:18-27

Kandeler E, Gerber H (1988) Short-term assay of soil urease activity using colorimetric determination of ammonium. Biol Fertil Soils 6:68-72

Karbin S, Hagedorn F, Dawes MA, Niklaus PA (2015) Treeline soil warming does not affect soil methane fluxes and the spatial micro-distribution of methanotrophic bacteria. Soil Biol Biochem 86:164-171

Keppler F, Hamilton JTG, Brass M, Rockmann T (2006) Methane emissions from terrestrial plants under aerobic conditions. Nature 439:187-191

King GM, Adamsen APS (1992) Effects of Temperature on Methane Consumption in a Forest Soil and in Pure Culture of the Methanotroph Methylomonas rubra. Appl Environ Microbiol 58:2758-2763

King JY, Reeburgh WS (2002) A pulse-labeling experiment to determine the contribution of recent plant photosynthates to net methane emission in arctic wet sedge tundra. Soil Biol Biochem 34:173-180

Kirschke S, Bousquet P, Ciais P, Saunois M, Canadell JG, Dlugokencky EJ, Bergamaschi P, Bergmann D, Blake DR, Bruhwiler L, Cameron-Smith P, Castaldi S, Chevallier F, Feng L, Fraser A, Heimann M, Hodson EL, Houweling S, Josse B, Fraser PJ, Krummel PB, Lamarque JF, Langenfelds RL, Le Quere C, Naik V, O'Doherty S, Palmer PI, Pison I, Plummer D, Poulter B, Prinn RG, Rigby M, Ringeval B, Santini M, Schmidt M, Shindell DT, Simpson IJ, Spahni R, Steele LP, Strode SA, Sudo K, Szopa S, Van Der Werf GR, Voulgarakis A, Van Weele M, Weiss RF, Williams JE, Zeng $\mathrm{G}$ (2013) Three decades of global methane sources and sinks. Nat Geosci 6:812-823

Knief C (2015) Diversity and habitat preferences of cultivated and uncultivated aerobic methanotrophic bacteria evaluated based on pmoA as molecular marker. Front Microbiol 6:-1346

Knief C, Lipski A, Dunfield P (2003) Diversity and activity of methanotrophic bacteria in different upland soils. Appl Environ Microbiol 69:6703-6714

Kolb S (2009) The quest for atmospheric methane oxidizers in forest soils. Environ Microbiol Rep 1:336-346

Kolb S, Knief C, Stubner S, Conrad R (2003) Quantitative detection of methanotrophs in soil by novel pmoA-targeted realtime PCR assays. Appl Environ Microbiol 69:2423-2429

Kozich JJ, Westcott SL, Nielson TB, Highlander SK, Schloter M (2013) Development of a Dual-Index Sequencing Strategy and Curation Pipeline for Analyzing Amplicon Sequence 
Data on the MiSeq Illumina Sequencing Platform. Appl Environ Microbiol 79:5112-5120

Le Mer J, Roger P (2001) Production, oxidation, emission and consumption of methane by soils: A review. Eur J Soil Biol 37:25-50

Luo GJ, Kiese R, Wolf B, Butterbach-Bahl K (2013) Effects of soil temperature and moisture on methane uptake and nitrous oxide emissions across three different ecosystem types. Biogeosciences 10:3205-3219

Maurer D, Kolb S, Haumaier L, Borken W (2008) Inhibition of atmospheric methane oxidation by monoterpenes in Norway spruce and European beech soils. Soil Biol Biochem 40: 3014-3020

Megonigal JP, Hines ME, Visscher PT (2004) Anaerobic Metabolism: Linkages to Trace Gases and Aerobic Processes. In: Schlesinger WH (eds), Biogeochemistry Elsevier-Pergamon, Oxford, pp 317-424

Milich L (1999) The role of methane in global warming: where might mitigation strategies be focused. Glob Environ Chang 9:179-201

Mohanty SR, Bodelier PLE, Conrad R (2007) Effect of temperature on composition of the methanotrophic community in rice field and forest soil. FEMS Microbiol Ecol 62:24-31

Mutschlechner M, Illmer P, Wagner AO (2015) Biological pretreatment: enhancing biogas production using the highly cellulolytic fungus Trichoderma viride. Waste Manag 43: 98-107

Nazaries L, Murrell JC, Millard P, Baggs L, Singh BK (2013) Methane, microbes and models: fundamental understanding of the soil methane cycle for future predictions. Environ Microbiol 15:2395-2417

Op den Camp HJM, Islam T, Stott MB, Harhangi HR, Hynes A, Schouten S, Jetten MSM, Birkeland N-K, Pol A, Dunfield PF (2009) Environmental, genomic and taxonomic perspectives on methanotrophic Verrucomicrobia. Environ Microbiol Rep 1:293-306

Ottow JCG (2011) Mikrobiologie von Böden. Springer- Verlag, Berlin Heidelberg

Petitjean C, Deschamps P, Lopez-Garcia P, Moreira D (2014) Rooting the Domain Archaea by Phylogenomic Analysis Supports the Foundation of the New Kingdom Protoarchaeota. Genome Biol Evol 7:191-204

Praeg N, Wagner AO, Illmer P (2014) Effects of fertilisation, temperature and water content on microbial properties and methane production and methane oxidation in subalpine soils. Eur J Soil Biol 65:96-106

Prem E, Reitschuler C, Illmer P (2014) Livestock grazing on Alpine soils causes changes in abiotic and biotic soil properties and thus in abundance and activity of methanogenic Archaea. Eur J Soil Biol 62:22-29

Robroek BJM, Jassey VEJ, Kox MAR, Berendsen RL, Mills RTE, Cécillon L, Puissant J, Meima-Franke M, Bakker PAHM,
Bodelier PLE (2015) Peatland vascular plant functional types affect methane dynamics by altering microbial community strcuture. J Ecol 103:925-934

Schaufler G, Kitzler B, Schindlbacher A, Skiba U, Sutton MA, Zechmeister-Boltenstern S (2010) Greenhouse gas emissions from European soils under different land use: effects of soil moisture and temperature. Eur J Soil Sci 61:683-696

Schinner F, Öhlinger R, Kandeler E, Margesin R (1996) Methods in Soil Biology. Springer, Heidelberg

Schleper C, Jurgens G, Jonuscheit M (2005) Genomic studies of uncultivated archaea. Nat Rev Microbiol 3:479-488

Song YT, Zhou DW, Zhang HX, Li GD, Jin YH, Li Q (2013) Effects of vegetation height and density on soil temperature variations. Chin Sci Bull 58:907-912

Steinkamp R, Butterbach-Bahl K, Papen H (2001) Methane oxidation by soils of an $\mathrm{N}$ limited and $\mathrm{N}$ fertilized spruce forest in the Black Forest, Germany. Soil Biol Biochem 33:145-153

Stiehl-Braun PA, Hartmann AA, Kandeler E, Buchmann N, Niklaus PA (2011) Interactive effects of drought and $\mathrm{N}$ fertilization on the spatial distribution of methane assimilation in grassland soils. Glob Chang Biol 17:2629-2639

Ström L, Ekberg A, Mastepanov M, Christensen TR (2003) The effect of vascular plants on carbon turnover and methane emissions from a tundra wetland. Glob Chang Biol 9:1185-1192

Ström L, Mastepanov M, Christensen TR (2005) Species-specific effects of vascular plants on carbon turnover and methane emissions from wetlands. Biogeochemistry 75:65-82

Ström L, Tagesson T, Mastepanov M, Christensen TR (2012) Presence of Eriophorum scheuchzeri enhances substrate availability and methane emission in an Arctic wetland. Soil Biol Biochem 45:61-70

Tate KR (2015) Soil methane oxidation and land-use change from process to mitigation. Soil Biol Biochem 80:260-272

Thornton PK, Ericksen PJ, Herrero M, Challinor AJ (2014) Climate variability and vulnerability to climate change: a review. Glob Chang Biol 20:3313-3328

Trotsenko YA, Khmelenina VN (2005) Aerobic methanotrophic bacteria of cold ecosystems. FEMS Microbiol Ecol 53:15-26

Urmann K, Lazzaro A, Gandolfi I, Schroth MH, Zeyer J (2009) Response of methanotrophic activity and community structure to temperature changes in a diffusive $\mathrm{CH}_{4} / \mathrm{O}_{2}$ counter gradient in an unsaturated porous medium. FEMS Microbiol Ecol 69:202-212

Wagner AO, Hofmann K, Prem E, Illmer P (2012) Methanogenic activies in alpine soils. Folia Microbiol 57:371-373

Wieczorek AS, Drake HL, Kolb S (2011) Organic acids and ethanol inhibit the oxidation of methane by mire methanotrophs. FEMS Microbiol Ecol 77:28-39

Willison TW, OFlaherty MS, Tlustos P, Goulding KWT, Powlson DS (1997) Variations in microbial populations in soils with different methane uptake rates. Nutr Cycl Agroecosyst 49:85-90 